This item was submitted to Loughborough's Research Repository by the author.

Items in Figshare are protected by copyright, with all rights reserved, unless otherwise indicated.

\title{
An examination of non-bank external funding for small and medium-sized enterprises in the UK
}

PLEASE CITE THE PUBLISHED VERSION

http://dx.doi.org/10.1080/02642069000000005

PUBLISHER

Routledge (@ Taylor and Francis)

VERSION

AM (Accepted Manuscript)

LICENCE

CC BY-NC-ND 4.0

REPOSITORY RECORD

Boocock, Grahame. 2019. "An Examination of Non-bank External Funding for Small and Medium-sized Enterprises in the UK". figshare. https://hdl.handle.net/2134/7661. 
This item was submitted to Loughborough's Institutional Repository (https://dspace.lboro.ac.uk/) by the author and is made available under the following Creative Commons Licence conditions.

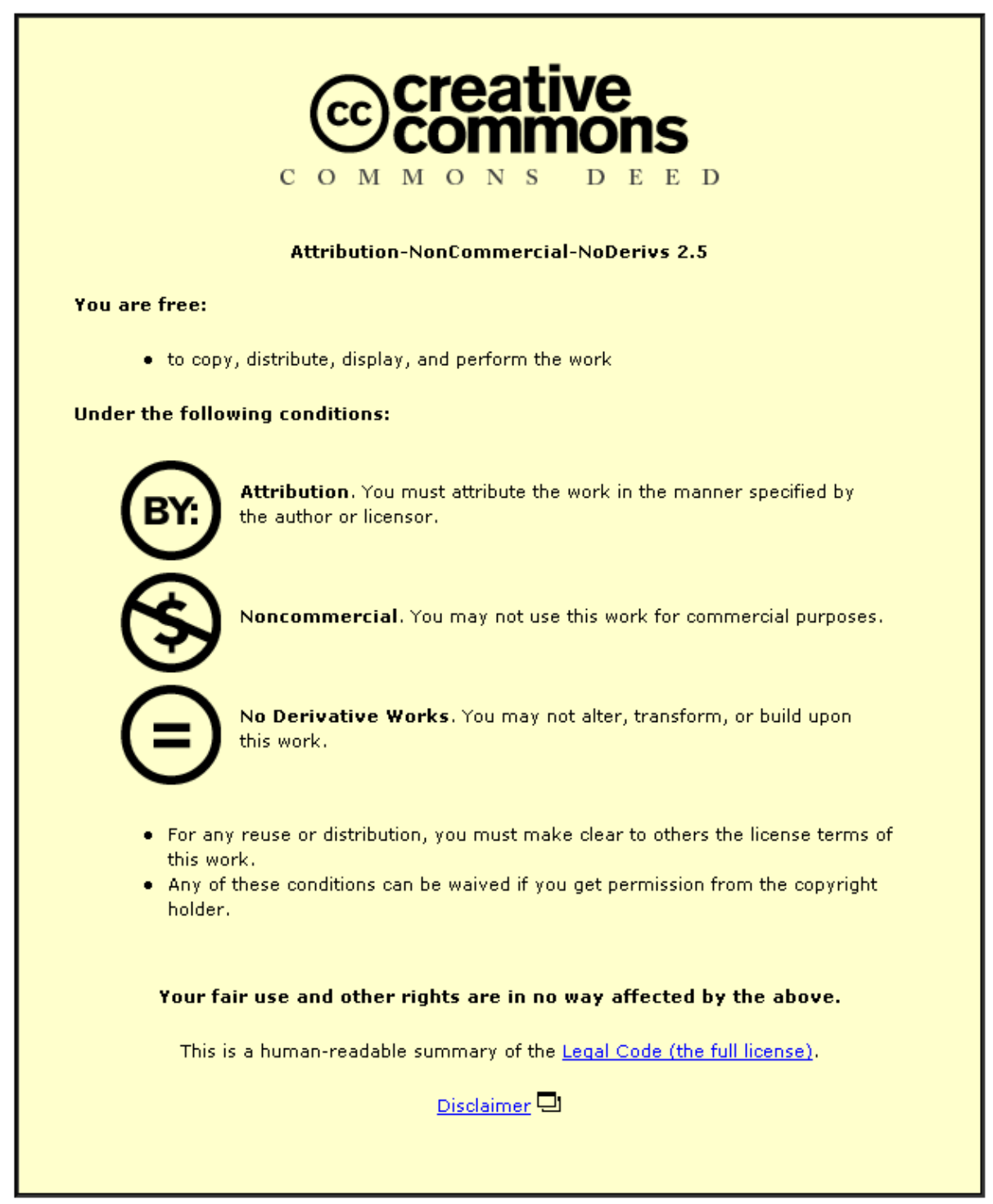

For the full text of this licence, please go to: http://creativecommons.org/licenses/by-nc-nd/2.5/ 


\section{An Examination of Non-Bank Funding for Small and Medium-Sized Enterprises in the UK}

by

J. G. Boocock*

This article reviews recent developments in the provision of long-term external funds to small and medium-sized firms in the UK; particularly, it attempts to establish how far the actions taken by a group of institutions, the specialist financial intermediaries (SFIS), have remedied perceived defects in the intermediation process. The activities of the SFIs are compared with those of the clearing banks, and the impact of government initiatives in this sphere is examined. While progress has undoubtedly been achieved in supplying external funds in amounts exceeding $£ 250,000$, attention still needs to be directed towards raising less than that figure and, especially, below $£ 100,000$.

* Department of Management Studies, Loughborough University of Technology, Loughborough, Leicestershire, LE11 3TU, UK. 


\section{INTRODUCTION}

The process of financial intermediation involves the channelling of funds between those people and institutions who wish to lend, and those who wish to borrow. In the eyes of the public, the major financial intermediaries are the banks and building societies, but other significant contributors to the intermediation process are the National Savings Bank, finance houses, unit trust groups, investment trust companies, pension funds and insurance companies. In recent years the activities and economic importance of these institutions have become increasingly recognised in the literature ${ }^{1}$ although relatively little analysis has been undertaken of the role of the so called 'specialist financial intermediaries' (SFIs) in the UK. This article seeks to rectify at least some aspects of this deficiency by examining the specialised activities performed by the most important groups of government agencies, quasigovernmental bodies, entities owned jointly by the public and private sectors and fully commercial entities which comprise this diverse sector of the UK financial system.

The specialist intermediaries discussed below provide an array of assistance to the business community in the UK, including: the granting of loans, possibly with subsidised interest rates; the provision of business premises; the offering of grants to certain qualifying institutions; and, of major relevance to this article, direct investment via the purchase of equity shares in companies. The variety of operations undertaken by the SFIs is broad and the rate of innovation in the delivery of facilities is substantial.

Therefore there must be some doubt as to the credibility of any analysis which seeks to deal with the activities of the SFIs en bloc. Consequently, this article focuses on the provision of long-term funds (equity capital and loans) to small and medium-sized enterprises, henceforth referred to as SMEs.

The objectives of the article can be summed up as:

- To identify deficiencies in the provision of funds to SMEs in the UK since the 1930s. 
- To sketch out the growth and activities of the venture capital sector.

- To describe briefly two measures introduced by the government to assist directly in the financial intermediation process: the Loan Guarantee Scheme (LGS); and the Business Expansion Scheme (BES).

- To highlight the role of official government bodies in the SFIs sector.

- To assess whether the initiatives and developments in this field have succeeded in plugging any perceived 'gaps' in the intermediation process.

- To consider the future prospects for the SFIs, including suggestions for new activities which may lead to a more efficient and effective supply of long-term funds to SMEs.

\section{HISTORICAL OVERVIEW}

A series of government-commissioned reports has identified gaps in the channelling of funds to SMEs. Problems were first highlighted [Cmnd 3897, 1931] when the Macmillan Committee on Finance and Industry recommended that an institution should be set up to provide long-term capital in amounts of up to $£ 200,000$.

Eventually, the forerunner of the 3i Group was established in 1945 to counter what became known as the 'Macmillan Gap'. Subsequently, the Radcliffe Committee [Cmnd 827, 1959] argued that there was still room for some further improvements in the financing of SMEs, but its main concern was addressed to the supply of funds to finance technical innovation.

However, it was not until 1971 that the Report of the Bolton Committee [Cmnd 4811, 1971] provided the first official detailed analysis of the role and financing of the small firm sector in the UK economy. The Report concluded, in the course of a wideranging summary, that small firms suffered a number of genuine disabilities in comparison with larger firms in seeking finance from external sources. While most of these disabilities reflected the higher costs of lending in small amounts or the higher risk of lending to small borrowers, an 'equity gap' was perceived in respect of raising funds in amounts below $£ 250,000$ which, adjusting for inflation over the intervening period, would represent amounts below about $€ 1$ million at current prices. In 
addition to this equity gap, Bolton stated there was an 'information gap', i.e. sources of finance, in general, were plentiful, but entrepreneurs were not aware of them.

The next study of small-firm financing was undertaken by the Wilson Committee. The Committee confirmed Bolton's findings in suggesting that small businesses suffered not so much from an overall lack of finance, but rather from a lack of suitable long-term funding whether equity or loans [Cmnd 7503, 1979]. Wilson also noted that small businesses were much more dependent on the banks for finance than were large companies, especially in the manufacturing sector. The gathering of evidence and the publication of the Committee's findings, from 1977 to 1979, spawned a number of initiatives such as the LGS and the BES.

While there has been no major investigation of SME funding since 1979, the debate on the efficiency of the financial intermediation process has certainly not died down in the 1980s. A typical contribution came from Robson Rhodes [1984: 45], when that firm reported on the early operation of the LGS. The Accountants stated that there was still a need for equity and long-term capital to be invested in those sort of businesses for which the LGS provides 'quasi-equity'. By contrast, other commentators suggest that there is now no general shortage of funds for good quality business propositions. This view was put forward, for example, in a recently published Report of the Confederation of British Industry [1987], although the CBI accepts that the financing costs for such ventures are sometimes high to compensate for the risk element involved.

Overall, however, the balance of opinion still contends that there are gaps in the funding of SMEs, particularly for long-term finance at the lower end of the financing spectrum.

Before examining the evolution of the SFIs and their efforts to meet these perceived needs, it is essential to clarify the role of the clearing banks in this respect. The Wilson Committee emphasised their importance but was concerned that the bulk of the lending was by way of overdraft and/or shorter-term loan facilities. Since 1979, the clearing banks have acted decisively to introduce a host of new lending services. While the overdraft remains the major external funding route for many SMEs, loans 
are now made available over 5,10 or even 20 years. Such loans often have the option to postpone capital repayments in the early years (although interest must be covered), and they may also be granted without the need to provide normal security.

In other countries term loans from the banking sector are an intrinsic and fundamental component of lending to SMEs, although the return on such loans to the lending institution may be linked to the success of the firm. Bankers in the UK argue that their reward, in terms of interest received on funds advanced via overdrafts or loans, means that some lending propositions from SMEs cannot be accommodated: that is, the return is not commensurate with the risk involved. Hence, despite considerable progress over the 1980s, developments in mainstream banking, according to a recent Report [NEDO, Mch. 1986: 3], 'do not attack the fundamental need, which is for a higher proportion of equity funding, particularly for start-up companies'. To meet this need, the four major clearing banks in the UK (as well as other banks such as the TSB and Citicorp) have each developed a subsidiary within their Groups to provide venture capital.

\section{VENTURE CAPITAL}

The emergence of the venture capital market has allowed entrepreneurial talent to be supported with finance and business skills, in order to exploit market opportunities; at the same time, long-term capital gains have been obtained by the financing institutions. In his detailed exposition of the venture capital sector in the UK, Lorenz [1985: 40] distinguishes two fundamental stages in funding of this nature: early stage, for example seed capital to fund initial research and development, and start-up costs of production; and later stage, covering such situations as expansion/development finance, turn-arounds and management buy-outs/buy-ins (MBOs/MBIs). The term venture capital has tended to be applied across all of these categories, although its classic definition as a high-risk injection of funds should strictly apply only to early stage financing.

In general, investments are made via an injection of equity finance or on the basis of a loan with an option to convert into equity, where the terms of conversion depend 
on the success of the investee company. An increasingly complex range of financial packages has been developed, combining elements of equity and loan funding. These 'hybrid' instruments are known under the generic title mezzanine finance. The tests of a good provider of venture capital are, first, to select the right investee from a host of applications for funds. Second, having tailored an appropriate financial package, the financier must be able to draw on a variety of industrial/commercial skills to support companies when their business environment turns sour.

The institutions offering funds of this type in the UK may be divided into two broad groups:

i. 'Captive funds' organisations which are owned and financed by the major banks and long-term investment institutions, such a pension funds. The most notable example of a captive fund is the 3i Group (formerly Investors in Industry), whose shareholders are the Bank of England (15 per cent) and the major banks (85 per cent). It remains by far the biggest venture capital company in the UK.

ii. The second group of institutions in this sphere is the newer, US-inspired independent funds which invite subscriptions from a wide variety of sources, for instance, funds are raised largely through approaches to financial institutions and private investors, through press advertisements, and through negotiated market loans. The number of specialist venture groups, such as Venture Founders and Thompson Clive, rose from less than a dozen in 1978 to around 130 in 1988, when they invested over $£ 600$ million.

The distinction between 'captive' and 'independent' fund is not clear-cut, either with regard to investment philosophy or mode of operations. Few independents are completely free of links with the major financial institutions, and the essential degree of autonomy required by a fund manager means that it would not be practical for captive funds to invest solely in accordance with the preference of their parent funding body. 
The 3i Group traditionally adopted a relatively passive approach to investment, with funds mainly being injected by way of long-term loans, coupled with a 'hands-off' style of portfolio management. However, from 1983 onwards, 3i and their counterparts in the clearing bank groups, started to operate on similar lines to the fast growing independent sector [Lloyd, 1988]. Thus, the captive fund managers started to focus more on capital gains, moving towards equity-oriented packages. They also started to invest more in early-stage ventures. Independent funds, for their part, sought to reduce the high risks associated with concentrating on mainly early stage investments by putting together a balanced portfolio consisting of companies at different stages of their development. Management Buy-Outs (MBOs) proved especially popular as they were perceived as less risky; such investment might only stay in the venture capitalists' portfolio for a short period before flotation.

It is possible to appreciate the scale and scope of the activities undertaken by the venture capital sector, as a whole, by considering figures collated by Venture Economics Ltd on behalf of the British Venture Capital Association (BVCA). By 31 December 1988, the BVCA had 107 members, representing every type of venture capital institution. The main features of the aggregated data (which exclude investments by members in other venture capital funds, as well as investments in quoted companies) are as follows:

a. Investment activity by BVCA members showed a substantial increase on previous years, approaching $£ 1.4$ billion, of which $£ 1.3$ billion was invested in 1,326 companies in the UK. The average size of each investment was $£ 684,000$ but the degree of syndication in the venture capital sector meant that the average size of each financing rose to $£ 957,000$.

b. Of the $£ 1.3$ billion invested, $£ 1.03$ billion (80 per cent) was invested in companies which had not previously received venture capital finance, with the remainder being directed at companies already in receipt of such funding. However the average size of the 1,123 new financings ( $£ 919,000)$ was slightly smaller than the corresponding figure ( $£ 1.1$ million) for the 233 follow-on financings. 
To assess the impact of this activity in closing any gaps in the intermediation process the allocation of the overall investment total is worthy of more detailed analysis (see Table 1).

TABLE 1

INVESTMENT BY FINANCING STAGE

\begin{tabular}{lrrrr}
\hline Stage & $\begin{array}{r}\text { No of } \\
\text { Fins. }\end{array}$ & $\begin{array}{r}\text { \% of } \\
\text { Fins. }\end{array}$ & $\begin{array}{r}\text { Amount } \\
\text { Invested (£m) }\end{array}$ & $\begin{array}{r}\text { \% of } \\
\text { Amount }\end{array}$ \\
\hline Start-up & 202 & 15 & 70 & 5 \\
Other Early Stage & 182 & 13 & 60 & 5 \\
Expansion & 639 & 47 & 402 & 31 \\
Buy-Out/Buy-In & 282 & 21 & 733 & 56 \\
Secondary Purchase & 51 & 4 & 33 & 3 \\
TOTAL & & & 1,298 & 100 \\
\hline
\end{tabular}

Source: Venture Economics Ltd.

The categories used in Table 1 are self-explanatory apart from 'Secondary Purchase' - the acquisition of existing shares in a company from another venture capital firm or another (other) shareholder(s). In terms of the Lorenz classification above, the first two categories of Table 1 would qualify as 'early stage' investments. These accounted for 28 per cent of the total number of financings, but amounted to only 10 per cent of the total sum invested. In the remaining five categories (Lorenz 'later stage' funding) there is a clear emphasis on MBO/MBIs; this category took up over 56 per cent of the total amount invested, yet represented only 21 per cent of the number of financings.

A further breakdown of the figures in Table 1 into the average size and number of investments by stage (see Table 2) indicates that financings of below, say, $£ 100,000$ must be comparatively rare.

The difference between the number of investments $(1,899)$ made by the individual members of the BVCA and the number of companies financed $(1,326)$ arises mainly 
because of syndicated investments, although some companies did receive more than one round of finance during the year. From Table 2, the average size of financing injected at the start-up and other early stages was $£ 347,000$ and $£ 330,000$ respectively. These figures are, in fact, down from 1986 ( $£ 512,000$ and $£ 371,000)$ as the recent inclusion of the $3 \mathrm{i}$ Group in the aggregate statistics reflects that institution's concern with financing at the lower end of the market for funds. In addition, Table 2 emphasises the funds committed to MBO/MBIs, although a number of major deals did distort the figure for the average size of financing.

TABLE 2

NUMBER AND AVERAGE SIZE OF INVESTMENT BY STAGE

\begin{tabular}{lrrrr}
\hline Stage & $\begin{array}{c}\text { No of } \\
\text { Invs. }\end{array}$ & $\begin{array}{c}\text { \% of } \\
\text { Invs. }\end{array}$ & $\begin{array}{r}\text { Ave. No } \\
\text { of Invs. } \\
\text { per fin. }\end{array}$ & $\begin{array}{r}\text { Ave. Size } \\
\text { of Fin. } \\
\text { (£000) }\end{array}$ \\
\hline Start-up & 251 & 16 & 1.24 & 347 \\
Other Early Stage & 230 & 11 & 1.26 & 330 \\
Expansion & 788 & 47 & 1.23 & 629 \\
Buy-Out/Buy-In & 545 & 23 & 1.93 & 2,600 \\
Secondary Purchase & 85 & 3 & 1.67 & 647 \\
& & & & \\
TOTAL & 1,899 & 100 & 1.40 & 957 \\
\hline
\end{tabular}

Source: As Table 1.

Finally, an examination of the venture capital sector would not be complete without a comparison of investment by investor type (see Table 3).

The overall size of investment was $£ 684,000$, with the largest investments on average being made by the captive subsidiaries of pension funds ( $£ 1$ million) and private independent funds $(£ 827,000)$. MBO/MBIs carry great weight in the portfolios of the above investors. Publicly-listed independent funds and the 3i Group made investments with average sizes of $£ 668,000$ and $£ 616,000$ respectively, while government-backed venture capital funds made the smallest investments with an average size of just $£ 146,000$. 
The 3i Group is clearly confirmed as the biggest venture capital supplier in the UK. The Group's Annual Report to 31 March 1988 revealed a further leap in its investment activities. The total amount invested worldwide was in excess of $£ 0.5$ billion, of which around $£ 400$ million was directed to companies in the UK.

TABLE 3

INVESTMENT BY INVESTOR TYPE

\begin{tabular}{lrrrr}
\hline Investor & $\begin{array}{r}\text { No of } \\
\text { Invs. }\end{array}$ & $\begin{array}{r}\text { \% of } \\
\text { Invs. }\end{array}$ & $\begin{array}{r}\text { Amount } \\
\text { Invested } \\
(\mathbf{E m})\end{array}$ & $\begin{array}{r}\text { \% of } \\
\text { Amount }\end{array}$ \\
\hline Independent - Private & 594 & 31 & 491 & 38 \\
Independent - Public & 211 & 11 & 141 & 11 \\
Captive - Bank & 207 & 11 & 192 & 15 \\
Captive - Pension Fund & 49 & 3 & 49 & 4 \\
Captive - Other & 46 & 2 & 21 & 1 \\
3i & 591 & 41 & 364 & 28 \\
BES & 78 & 7 & 22 & 2 \\
Government & 123 & 100 & 18 & 1 \\
TOTAL & & & & 100 \\
\hline
\end{tabular}

Source: As Table 1.

In view of the importance of the venture capital sector, it is worth summarising developments in the sphere.

i. The independent groups in the mid 1970s backed a succession of start-up propositions, many of which failed, mainly in the high-technology field. In their activities in the 1980s the independent funds often stand accused of moving away from their original ethos. In particular, they are now said to adopt a short-term view, concentrating on making quick profits for their investors rather than on the longertime horizon. While some firms strongly refute such criticism, there does seem to be a trend towards safer investments in order to preserve scarce managerial resources. To illustrate this, there has been a noticeable shift in the UK venture capital market 
away from investments in consumer-electronics related companies towards the consumer-related and 'other services' areas. Coupled with this, mention has already been made of the concentration on MBOs, while many investors are injecting second-stage finance to supplement existing investments in the light of a proven track record.

The 'captive fund' manager, by contrast appears to be more able to take a long-term perspective as the parent (bank, pension fund or other institution, e.g. British Coal) tends not to press for high dividends or the early realisation of capital gains. (3i Group seek a compound return of around 20 per cent, perhaps marginally below the remainder of the captive sector, but considerably below the target return of the independent funds.) Therefore, there is less likelihood of pressure being exerted on the investee company to, say, achieve an early flotation or to sacrifice its independence in being acquired by a trade buyer. This tolerance enables businesses receiving funds to ride out cycles in the stock markets, especially such events as 'Black Monday' of October 1987.

ii. The 'equity gap' at the lower end of requests for funding appears to be still in evidence. While the explosion in venture capital activity over recent years implies that there was a gap in the supply of funds to the small business sector, this was mainly fuelled by a set of favourable circumstances in respect of the exit routes by which equity investments could be off-loaded; in particular, the junior stock markets experienced rapid growth providing fertile ground for flotation; the recent merger and acquisition boom sparked off the trade sales of smaller companies to larger concerns; and legislation was passed enabling companies to repurchase their own shares.

However, the role of providing smaller sums where the exit route is less certain is increasingly being left to the $3 \mathrm{i}$ Group, government-backed institutions and government initiatives such as the BES and LGS. The general feeling is that an investment of, say, below $£ 100,000$ does not justify the management time required to assess and monitor the client company's prospects. This upward drift in investment levels appears to be in excess of the rate of inflation. Even in the captive 
fund sector, the lowest investment considered by the venture capital arms of the UK Clearing Bank Groups, is around $£ 200,000$.

Some specialist funds have been set up to provide seedcorn finance, but they tend to be small and to operate within a limited geographical area and/or industrial sector (e.g. biotechnology).

Apart from the effort required to assess a proposal for smaller amounts, all venture capitalists are concentrating on increasing the proportion of their time spent on adding value to their existing portfolios. In the 'post-October 1987' climate, those funds with a portfolio of companies approaching flotation are perhaps having to wait a little longer before taking their profits. Although the Stock Exchange has recovered somewhat, pulling up the USM and the Third Market in its train, venture capitalists may be able to provide interim funds to companies awaiting flotation. Alternatively, listed companies may seek venture capital syndications rather than perform a rights issue on a stagnant market.

\section{INDIRECT GOVERNMENT MEASURES}

The focus of this article is on the ability of SFIs to provide longer-term finance to SMEs. Two government measures have particular relevance in this context: the Small Firms Loan Guarantee Scheme (LGS) and the Business Expansion Scheme (BES). These initiatives are intended to facilitate and encourage the activities of private sector institution and individuals in respect of the financial intermediation process.

\section{The Loan Guarantee Scheme}

The LGS was introduced in 1981 on the strength of a recommendation in the Wilson Committee Report. Certain banks and other financial institutions are encouraged to supply medium-term (2-7 years) loan finance, up to a maximum of $£ 100,000$, where the risks are considered too great to justify conventional lending. To counter these risks, the government guarantees 70 per cent of any loan approved. In return, the borrower - sole trader, partnership or limited company - pays interest on the loan plus a premium of 2.5 per cent of the amount guaranteed. 
Applicants for finance of this nature are required to produce a business plan before approval, and regular management accounts thereafter. In addition, personal security, where available, is now expected to be pledged in support of conventional borrowing lines, with the LGS to be utilised as a 'top-up' facility. These changes were introduced in 1984 and they led to a dramatic reduction in LGS borrowing (see Table 4).

Since the low point of 1985-86, the government has consistently demonstrated its commitment to the LGS, reducing the premium to its present level in 1986, and increasing the maximum amount of the loan from $£ 75,000$ to $£ 100,000$ in early 1989.

TABLE 4

THE LOAN GUARANTEE SCHEME

\begin{tabular}{lrrr}
\hline Year & No of Loans & $\begin{array}{r}\text { £: Average } \\
\text { Amount }\end{array}$ & $\begin{array}{r}\text { Em } \\
\text { Value }\end{array}$ \\
\hline $1984 / 5$ & 2,084 & 33,300 & 69.4 \\
$1985 / 6$ & 542 & 32,700 & 17.8 \\
$1986 / 7$ & 1,050 & 38,400 & 40.4 \\
$1987 / 8$ & 1,234 & 37,500 & 46.2 \\
$1988 / 9$ & 2,291 & 28,300 & 64.8 \\
\hline
\end{tabular}

Source: Loan Guarantee Unit, Department of Employment.

Any attempt to gauge the impact of the LGS, or any of the measures described in this article, is complicated by a host of environmental factors. Harrison and Mason, in an article which focused on the regional impact of the LGS, summarised the problems of measuring the success or otherwise of the scheme [1986: 540]. For example, 'take-up' rates may vary between regions if entrepreneurial flair and talent is not evenly spread throughout the UK. In addition, '... Of at least equal importance are the existence and magnitude of additionality and displacement effects and the wastage rate arising from the failure of assisted firms'. 
The wastage rate of failed firms is substantial, but the concept of 'additionality' is perhaps even more crucial. Robson Rhodes in their study of the early operation of the LGS suggest that less than one half of the loans issued under the Scheme were genuinely additional. Of particular concern was, what the Accountants described as, the 'lurch' to the LGS [1984: 88]: 'By this we mean that a proposal which proceeds some way to conventional finance, suddenly emerges as being 100 per cent financed under the LGS.' This may have been true in the early years of the LGS, but bankers contend nowadays that the Scheme is either used as a genuine 'fall-back' facility after conventional lending avenues have been exhausted or that it has been supplanted by attractive new loan facilities offered by the banks. One wonders whether the phenomenally successful company, Sock Shop, which started life with the help of a LGS loan of $£ 45,000$, would now be granted a loan without guarantee support!

After six years of the LGS, 17,648 loans worth $£ 579$ million had been guaranteed at a net cost to the government of $£ 109$ million. Loans worth $£ 146$ million had been written off as bad debts and income raised through the premium amounted to a mere $£ 37$ million [Comptroller and Auditor General, Department of Employment and Training Commission 1988]. The LGS has never recovered the momentum generated in its early years. Its critics maintain that the whole concept is flawed - by definition it is a loan rather than equity and hence the LGS will always be inappropriate to meet the financing needs of smaller enterprises. Nevertheless, when the LGS came up for review in early 1989, it was extended indefinitely. The decision naturally weighed the cost of operating the LGS against the likelihood of the banks and the SFIs providing finance in a similar form. The Department of Employment clearly felt that there was still a gap in the financial intermediation process for funding of this nature.

\section{Business Expansion Scheme}

The BES was introduced in the Finance Act 1983 and was designed to increase the amount of equity capital available to non-quoted companies. Its basic format is straightforward, although amendments have been made since its inception to prevent 'abuse'. 
Under the BES any investor not closely connected with the company can obtain tax relief on a sum of up to $£ 40,000$ per annum which is invested in new ordinary ('fullrisk') shares of qualifying unquoted companies. Thus, an investment of $£ 40,000$ will cost a top-rated tax payer (currently taxed at 40 per cent) only $£ 24,000$ after tax relief - hence its obvious attractions despite the reduction in the tax rates implemented in the 1988 Finance Act. In addition, the proceeds of any shares purchased under the terms of the BES, since 1986, are free of Capital Gains Tax (CGT) upon disposal.

The most popular method of raising BES cash is through a direct issue of shares to the public. This can be done via a private placing (usually arranged through a stockbroker), through an approach to investors without any professional help, or by publishing a public prospectus. The latter method has raised the bulk of funds under the BES over recent years. (None of the 'direct issue' routes of fund-raising can be classed as financial intermediation, but the scheme is clearly an important device for tapping directly primary sources within the private sector.) The other route by which the BES can be utilised is for an investor to join a fund, which invests in a spread of companies.

These funds can be of two types: approved which are usually closed funds operated in accordance with strict conditions laid down by the Inland Revenue; and open ended or managed which adopt a much more flexible approach. Whichever type of fund is chosen, the investor is hopeful that if a small number of investments in the portfolio fail completely, one outstanding success can still more than compensate. Fund managers tend to offer managerial back-up to the investee companies, and they will often take options on the shares, typically ranging from 5 per cent to 10 per cent of the equity capital.

From the company's point of view, a major advantage of raising finance under the BES is the likely easing of pressure from outside investors, arising from the condition that investors cannot sell shares purchased before five years has elapsed without losing the tax relief. Furthermore, the company is helped by the absence of annual interest commitments and capital repayments, and gearing is not affected detrimentally, as occurs when funds are raised under the LGS. 
According to the official statistics issued by the Inland Revenue, investment via the BES climbed from $£ 105$ million in $1983-84$, the first year of its operation, to $£ 167$ million in the latest set of official figures covering 1986-87. More than 2,400 small businesses received BES finance during the first four years of its existence. Although there are problems in compiling accurate data, Investment and Tax Planning Services (ITPS) estimate that the total funds raised under the BES, excluding non-prospectus direct investments by individuals, showed a further increase, approaching $£ 180$ million in 1987-88. A detailed analysis of investment made is set out in Table 5.

The BES was designed to attract 'speculative' funds offering a high return, with tax relief providing some compensation for the degree of risk involved. Despite its apparent success the BES has tended to attract funds to relatively lower risk businesses, as asset-backed ventures such as property development have found favour with investors. The 1986 Finance Act attempted to remedy these faults by ruling that businesses with more than one half of their net assets in land or buildings would no longer qualify for BES support, unless they were raising less than $£ 50,000$ in any one tax year. This amendment, together with the exemption from CGT also granted in 1986, coincided with the publication of a long-awaited report by Peat Marwick which, on the whole, gave warm approval to the BES. On the positive side, the scheme had generated finance for companies which would not have occurred in its absence. Moreover, about one third of a sample of 102 companies surveyed by Peat Marwick raised less than $£ 50,000$ each under the terms of the BES, although this accounted for just 3 per cent of the total funds raised by the sample companies. A more disturbing aspect of the early stages of the BES related to the utilisation of the funds raised [Peat Marwick, 1986: 14].

... BES has not been a significant source of seedcorn capital ... (funds have been) used predominantly to provide working capital to companies suffering from liquidity crises and seeking to expand, and companies seeking to finance the purchase of existing businesses. 
TABLE 5

BUSINESS EXPANSION SCHEME: 1983-88

\begin{tabular}{|c|c|c|c|c|c|c|c|c|c|c|}
\hline \multirow[b]{2}{*}{ Type of Investment } & \multicolumn{2}{|c|}{$1983 / 4$} & \multicolumn{2}{|c|}{$1984 / 5$} & \multicolumn{2}{|c|}{$1985 / 6$} & \multicolumn{2}{|c|}{$1986 / 7$} & \multicolumn{2}{|c|}{$1987 / 8$} \\
\hline & $I / C^{(1)}$ & $\begin{array}{l}\text { Amt } \\
(£ m)\end{array}$ & I/C & $\begin{array}{l}\text { Amt } \\
(£ m)\end{array}$ & $\mathrm{I} / \mathrm{C}$ & $\begin{array}{l}\text { Amt } \\
(£ m)\end{array}$ & $\mathrm{I} / \mathrm{C}$ & $\begin{array}{l}\text { Amt } \\
(£ m)\end{array}$ & $\mathrm{I} / \mathrm{C}$ & $\begin{array}{r}\text { Amt } \\
(£ m)\end{array}$ \\
\hline $\begin{array}{l}\text { Funds: Approved \& Managed } \\
\text { Average investment }\end{array}$ & 205 & $\begin{array}{r}47.10 \\
0.23\end{array}$ & 220 & $\begin{array}{r}49.90 \\
0.23\end{array}$ & $\overline{182}$ & $\begin{array}{r}37.20 \\
0.20\end{array}$ & $\overline{117}$ & $\begin{array}{r}32.90 \\
0.28\end{array}$ & 100 & $\begin{array}{r}35.10 \\
0.35\end{array}$ \\
\hline $\begin{array}{l}\text { Prospectus Issues } \\
\text { Average sum raised }\end{array}$ & 34 & $\begin{array}{r}38.50 \\
1.13\end{array}$ & 74 & $\begin{array}{r}79.80 \\
1.08\end{array}$ & 104 & $\begin{array}{r}109.70 \\
1.05\end{array}$ & 52 & $\begin{array}{r}115.20 \\
2.22\end{array}$ & 76 & $\begin{array}{r}138.40 \\
1.82\end{array}$ \\
\hline $\begin{array}{l}\text { Direct investment* } \\
\text { Average Investment }\end{array}$ & 476 & $\begin{array}{r}24.80 \\
0.05\end{array}$ & 513 & $\begin{array}{r}18.20 \\
0.04\end{array}$ & 416 & $\begin{array}{r}11.10 \\
0.03\end{array}$ & 535 & $\begin{array}{r}18.90 \\
0.04\end{array}$ & $N / A^{(2)}$ & $\begin{array}{l}\text { N/A } \\
\text { N/A }\end{array}$ \\
\hline TOTAL: All Sources ${ }^{\star *}$ & $\underline{715}$ & 105.00 & $\underline{807}$ & $\underline{147.90}$ & $\underline{702}$ & $\underline{158.00}$ & 704 & $\underline{167.00}$ & N/A & $\mathrm{N} / \mathrm{A}$ \\
\hline Average & & $\underline{0.15}$ & & $\underline{0.18}$ & & $\underline{0.23}$ & & $\underline{0.24}$ & & N/A \\
\hline
\end{tabular}

Source: Inland Revenue, Investment and Tax Planning Services. Format adapted from Small Business Research Trust Report, 1988.

Key: (1) I/C: number of investee companies

(2) N/A: figures not available

(*) Balance after subtracting ITPS data on fund investments and prospectus issues from the Inland Revenue totals. The Revenue classify all of the following - managed funds, prospectus issues, private placings and ad hoc individual investments - under 'direct investment'.

(**) Official Inland Revenue statistics for the fiscal year. 
The generally favourable assessment of the impact of the BES has been brought into question by a recently published Report, funded by the Small Business Research Trust [Mason, Harrison, Harrison, 1988]. In the course of a thorough and wide-ranging review, the authors highlight a number of worrying trends. Of particular relevance to this article are their observations on the equity gap and, also, the type of businesses financed under the scheme.

With regard to the former, the key issue is the proportion of BES funds that are now being devoted to prospectus issues at the expense of investments made directly or via a fund. To mitigate the emphasis on larger sums being raised under the BES, the 1988 Finance Act introduced a limit of $£ 500,000$ on the amount that a company could raise in any one financial year. This limit should effectively end the domination of the scheme by large prospectus issues for single companies (the only exceptions being the $£ 5$ million ceilings for ship-chartering and the newly-qualifying area of residential property letting). Critics, such as Steven Rowe of BES Investment Research, suggest that the standard limit of $£ 0.5$ million is far too low and that it will divert substantial funds into the residential property market which would otherwise have gone into genuine businesses.

A second observation from the SBRT Report [1988: 4] confirms the doubts of those observers who worry that the BES has deviated from its original intention. While in 1986-7, the last year for which official statistics are available, 90 per cent of the total amount invested went to young and very young start-up companies, the type of business supported tends not to be high-risk. In particular, '... the bulk of the finance raised ... has been invested in service sector businesses, often asset-related, and predominantly in the wholesale, retail, real estate and leisure sectors'.

Despite its shortcomings, the BES has undoubtedly established itself as an attractive route for financing the expansion plans of certain categories of small businesses. The recent amendments to the scheme are designed to consolidate its role as a source of long-term funds to a wider variety and number of SMEs. 
In addition to the above-described government measures to assist with the financial intermediation process in respect of business borrowers, there are several other official schemes which are designed to support business activity directly, and which effectively complement the other finance provision facilities. Within this context the government sector may be thought of as acting as an intermediary between taxpayers (who are given no freedom to determine the use of their funds) and recipient businesses. However, to the extent that the official on-lending bodies charge interest on loans or look for an off-loading of equity shares in the long term, public sector coffers should obtain at least some return.

Assistance on a geographical basis is provided by such bodies as the Rural Development Commission in England and the Welsh Development Agency. The facilities provided by these two institutions are similar, although probably less welldeveloped, than those offered by the Scottish Development Agency (SDA). In addition to advice and encouragement, the agencies are a source of finance. Equity and medium- and long-term loans can be provided for developing businesses, and capital funds can be made available to promising new, but high-risk, enterprises. The work of the SDA and WDA deserves separate treatment and is necessarily mentioned only briefly here.

Apart from the agencies outlined above there are a host of government, EEC and local authority initiatives to help firms on a regional basis. On a national scale, government policy towards business (and innovatory enterprises, especially) can be illustrated by reference to the activities of the British Technology Group (BTG), which is closely associated with the DTI.

BTG is the name under which the National Research Development Corporation (NRDC) and the National Enterprise Board (NEB) have been co-operating since 1981 following the government's decision to combine the two organisations. The NEB was established in 1975, drawing funds from the government, in order to provide support for industrial investment. However, in 1979, the incoming Conservative government, instituted a major change of policy to curtail such direct 
investment and since that time NEB investments are being restored to the private sector.

By contrast, the other element of BTG, the NRDC, has always operated in a manner more in tune with the present government's philosophy. Thus the NRDC is selffinancing and its main objective is to provide finance for technological innovation and particularly the transfer of academic research into commercial products. On behalf of academic and research institutions, BTG will negotiate licence agreements with the manufacturers, sharing the licence royalties, under a revenue sharing agreement. It will provide finance for research and development and, in some cases, help startup companies. Apart from this matching of new ideas with the requirements of potential users, BTG also offers assistance to companies which have promising new technology but lack the funds or expertise to undertake the project alone.

\section{THE IMPACT OF RECENT DEVELOPMENTS}

The developments outlined above, albeit in a somewhat cursory manner, can now be assessed to gauge their overall impact. The measures introduced embrace a wide variety of equity and loan finance, but their impact is increased as they tend to complement one another, rather than to overlap or duplicate each other.

Furthermore, the financial institutions frequently work together in assessing a project in order to enhance the package of finance which may be made available to a company.

At the outset, the dominant role of the clearing banks was stressed. In providing funds to SMEs, the banks have been moving away from traditional 'on-demand repayment' overdraft finance towards longer term facilities. The culture of the banking community is moving towards a much more ready acceptance of an element of risk in business propositions, even where security may be lacking. At some point, however, the degree of risk perceived by a bank may mean that a proposal is declined, as an acceptable risk/reward trade-off cannot be achieved. The entrepreneur may then be directed to the venture capital 'arm' of the bank. 
Alternatively, the banks also provide funds to high risk ventures through their involvement with the LGS. In the early stages of the operation of the LGS, Robson Rhodes [1984] suggested that nearly half of the early users of this Scheme would have been able to obtain finance from commercial sources if they had been willing to pledge personal security. However, the survey did conclude that the LGS frequently supplied capital to small businesses where finance was unavailable from any other source. The Department of Employment announced an indefinite extension of the LGS in early 1989.

New sources of pure equity include the BES, which has thrived since its inception in 1983. It has already been noted (see Table 5 and subsequent comments) that prospectus issues account for the bulk of the funds raised; such fund-raising exercises under the BES rarely raise less than $£ 250,000$, except where the issue fails to attract investors, and the average amount raised per prospectus was in the region of $£ 2$ million in 1987-88. However, the limit of $£ 0.5$ million imposed in the Finance Act 1988 should obviously choke off this trend. At the other extreme, the modest proportion of BES funds devoted to individual direct investments ( $£ 19$ million in 1986-87 with an average injection of $£ 35,000$ ) clearly has the potential to make some impact on the equity gap in the $£ 10,000$ to $£ 50,000$ range.

Genuine financial intermediation is undertaken by the BES fund managers, but the average investment by such bodies is now around $£ 350,000$ and, indeed, is rising. While investments below $£ 100,000$ do exist, the typical purchase of equity is much higher. Overall in 1986-87, 73 per cent of the companies financed received $£ 100,000$ or less, although this accounted for only 8 per cent of the $£ 167$ million raised. After allowing for individual direct investments, the fund managers clearly do not invest a great deal of their resources in small amounts.

In a survey undertaken for a recent NEDO Report [Sept. 1986: 10], it was stated that '... many companies suggested that the BES needed to be directed specifically to high growth companies and to be modified to encourage investment by individuals connected with the business'. These suggestions have been endorsed by most practitioners and academics, especially the relaxing of the rule which forbids investments under the BES by 'connected' individuals. To foster the channelling of 
funds to high growth companies, a number of recommendations were put forward in the recent SBRT Report [Mason, Harrison, Harrison, 1988], referred to above. Investments made by individuals directly or via a fund are considered to be more in line with the spirit of the BES than prospectus issues which are perceived as comparatively safe. Investments could be drawn to the former by amendments in the strict taxation rules of the BES, as well as by establishing 'marriage bureaux' to put prospective investors in touch with companies in need of equity. In the light of the 1988 Budget amendments, it must be questionable, however, whether major modifications to the BES will be introduced in the near future.

It should be recognised that, for larger companies, pure equity is accessible through syndicated venture capital and, especially, the junior stock markets. On the latter, the amounts raised on flotation range from a minimum of $£ 500,000$ to over $£ 5$ million. The rather limp progress of the Third Market since its inception in January 1987 may be given a boost by the recently imposed limit of $£ 0.5$ million p.a. on BES prospectus issues: that is, more companies may choose to go for flotation rather than issue a BES prospectus. (In addition a host of companies in receipt of BES finance may start to move on to the Third Market to enable investors to relinquish their equity stakes.)

New sources of mixed loans and equity, tailored to the individual needs of small businesses are offered by venture capital funds and by a number of the publicly backed institutions such as the SDA. The average amount invested per company in 1988 by the members if the BVCA was $£ 684,000$, despite the inclusion of the $3 i$ Group statistics. The structural differences in the support provided under the BES initiatives and through venture capital activities, noted in the 1986 NEDO Report on the provision of external capital for small firms [NEDO March 1986: 10], still hold true:

... In part the differences in size of investments between BES and other venture funds may reflect the fact that approved BES funds only invest in ordinary shares with the result that their contributions may be geared up from other sources, whereas the typical venture capital funds may make use of a variety of financing instruments including preferred or deferred shares. 
However, it was then suggested that a pattern might emerge in which a company raises finance in three stages, initially via the BES; follow-on financing from an institutionally backed venture capital fund if profitable growth exhausts the first tranche of funds; and, finally, flotation, some years later, on one of the junior stock markets. There is no evidence that such a scenario operates on a wide scale at present, but the recent move to divert funds away from BES prospectus issues could possibly lead to the belated fulfilment of the pattern of finance predicted above.

It may thus be concluded that in an increasingly sophisticated financial environment, a range of financing instruments has been developed that offers greater flexibility with respect to debt subordination, participation in profits and the timing of repayments. In theory, the arrangements now in place should meet the particular financing needs of any SME, whether a start-up or existing business, even where there is a degree of risk involved. However, the question still arises as to whether the financing 'gaps' identified at the beginning of this article have been filled. In 1971 the Bolton report identified an equity gap for amounts below $£ 250,000$ which, after allowing for inflation, would today represent amounts of below $£ 1$ million. Progress has undoubtedly been achieved in providing the right type of funding arrangements at the upper end of this range, but, it is generally, though not unanimously, agreed that attention still needs to be directed towards the difficulties of raising finance below the $£ 100,000$ level.

A comparison of the above described sources of funds for SMEs is given in Appendix 1. This confirms the contention that recent developments have had a major impact on the provision of equity-linked finance to meet requirements of $£ 100,000$ or more. However, below this figure support is more limited. For example, as stated in the venture capital section above, the latest BVCA statistics reveal that only 28 per cent of financings (accounting for 10 per cent of the total amount invested) are directed towards early stage financing; and only a fraction of this allocation has gone for seed-corn capital to finance product development before commercialisation. Indeed, the BVCA set up a committee in early 1989 to investigate the problems of securing risk finance for small and/or technology-related projects. The findings of this committee should be available by early 1990 . 
Within the range of SFIs featured in this review, it is central and local government initiatives which are adopting a major role $n$ the financing of business start-ups. This appears to have been recognised by representatives of the small business community. For example, the Union of Independent Companies [Financial Times, 28 February 1989] called for the creation of a $£ 1$ billion government-funded Business Development Board to provide cheap-rate loans for up to 10 years to small and medium-sized companies.

At this stage, it might be argued that an apparent lack of appropriate financing arrangements for seed corn/start-up propositions seeking modest sums reveals an anomaly in the present UK government's free market outlook. As a tentative, albeit unproved conclusion, it might be suggested that the private sector financial institutions, in general, and the banks, in particular, with their unrivalled knowledge of their customers' operations, are now relatively efficient in appraising the future prospects of SMEs; hence any viable business proposition offering an acceptable trade-off between risk and return should surely be accommodated by the private sector and additional viable lending must be scarce. Nonetheless, government action has consistently been taken to fill perceived gaps in the financial intermediation process. The resolution of this apparent dichotomy is considered in the concluding section, as part of a general assessment of the future prospects for the specialist intermediaries in the UK.

\section{FUTURE PROSPECTS FOR THE SFIS}

There is widespread recognition of the importance of the small business sector, and of the value of its contribution to the health of the national economy. The availability of financial support to this section is, therefore, an issue of the utmost significance. In areas such as seed corn finance, where the private sector appears to have held back because of the perceived high risks inherent in small unquoted companies, and because of the diseconomies of small-scale provision, government schemes are likely to continue to play a significant role. Nevertheless, the importance of the position of the specialist intermediaries and financing initiatives within the UK 
financial system cannot be over-emphasised, especially in respect of the longer-term development of the UK's industrial and commercial base.

The debate on the existence of an 'equity gap' is not entirely one-sided - the venture capitalists, in particular, see the problem not as a shortage of funds, but as a lack of good quality small-business ventures being presented for approval. There is a very high rejection rate for such applications - venture fund managers are reported to accept a mere 1 to 3 per cent of the proposals put to them. Clearly, would-be entrepreneurs must often feel that they have sound ideas worthy of support, and that the venture capitalists are able to 'pick the cherries from the small business cake' [Batchelor, 1988]. While the financiers will obviously take a more objective view of the proposals put to them, a common defect in the many applications for funds relates to the presentation of the business plan; in addition, the potential supplier of the funds will need to be convinced of the adequacy of financial control and monitoring within the borrowing organisation.

Alternatively, even if a proposal is attractive to a potential backer, and a properly formulated business plan has been compiled, the owners of the business may ultimately withdraw their application if they are required to surrender some of their equity. A recent NEDO Report [Sept. 86: 3] suggests that '... management education (in the electronics industry) be directed towards increasing awareness of the potential role of external equity capital in financing rapid expansion from a modest base'. It might be argued that the venture capitalists should also attempt to publicise more forcefully the benefits of their services, especially if they could indicate clearly the basis on which their required equity stake would be calculated.

To summarise, this article has identified two major gaps which are perceived in the financial intermediation system. Recent developments in the supply of funds would appear to have made important contributions to closing the 'equity gap' in respect of the financing needs of smaller businesses. In addition, considerable efforts have been made to disseminate information (the Bolton Committee's information gap) on the financing options now available. Further progress is required on a number of fronts: 
- The situation for smaller businesses could be improved through higher standards of education and training for their owner managers, especially in relation to the drawing up of business plans.

- There is also a need to place emphasis on filling the remaining gaps in the sources of smaller amounts of funds at the earliest stages of business operations.

The following areas for further research are identified:

- To assess the scale of the problem or, indeed, to confirm that a problem exists at the lower end of the financing spectrum, it is essential to identify the number and characteristics of those companies adversely affected by a lack of appropriate finance [NEDO July 1986].

- It has been noted that the 3i Group and government-backed agencies appear to be more willing to provide equity or equity-linked finance in lower amounts than, say, the independent venture capital groups. The performance of the companies supported by the former institutions should be closely monitored. If they show strong growth trends in terms of profits and cash-flow, then the private sector may increasingly be persuaded to assist such businesses. It could then be argued that the financial market is efficient and that the currently perceived gap is only a temporary phenomenon. Support for such a scenario is given by the experience of the NRDC, part of the BTG; that institution has been able to adopt a lower profile in providing loan finance over recent years, as the private sector has proved more willing to provide funds for high technology projects. Conversely, if the companies presently supported by $3 \mathrm{i}$ and government-backed bodies prove to be prone to failure and/or show sluggish growth tendencies, then the current pattern of financing is likely to become entrenched. It will be interesting to observe whether the present UK government, in view of its stated commitment to small businesses, is content to support what might be termed 'second-rate' business propositions (those turned down by the privately-owned financial institutions).

- Two principal reasons have been put forward to explain the existence of any financing gaps: the riskiness attached to small business funding and the high fixed 
costs of the risk assessment procedures. These two issues overlap to a large extent and provide scope for research.

It has been suggested [NEDO, July 1986] that the government might assist the intermediation process by providing a subsidised appraisal scheme, to counter the high fixed costs, rather than, say, a subsidised loan scheme. (Support to assist in the appraisal of business ventures does exist in the shape of a number of ad hoc government schemes, such as the DTI's 'Joint Appraisal Scheme', but there is no generally recognised network to aid investors in the assessment process.) Such a proposal naturally depends on establishing a consensus view on the appropriate method of identifying and assessing the risk applying to various business projects.

The search for identifying the fast-growing businesses, from the whole population of small and medium-sized firms, was taken up by Storey et al. [1987]. The authors offer a wide-ranging review of the performance of small firms and of particular relevance to this article is their conclusion that selective assistance to fast-growing firms will prove effective, rather than general assistance available to all small firms. No 'identikit' successful small enterprise is identified, but certain characteristics are highlighted. These include asset and employment growth (three times as large as the average company), lower trading profits but higher net profits, and professional directors with other corporate interests. However, problems arise for possible private backers or government funding agencies:

... both public and private initiatives would be targeted at the growers but, because the firms growing fast in terms of employment are not always the same as those growing fast in terms of assets or profitability, the same firms are not necessarily the target for public policy and private sector interest.

This would imply that the financing propositions undertaken by the governmentbacked bodies are not 'second-rate' but of a different nature. However, the 'consensus view' of identifying and assessing the risk of business ventures and, hence, simplifying the appraisal procedures for financial institutions is not yet established, and further research in this area is vital. 
APPENDIX 1

SOURCES OF FUNDS TO SMES (£000)

SPECIALIST FINANCIAL INTERMEDIARIES: SELECTED INSTITUTIONS

\begin{tabular}{|c|c|c|c|c|c|c|}
\hline \multirow[b]{2}{*}{ SOURCE } & \multicolumn{3}{|c|}{ RANGE* } & \multirow[b]{2}{*}{ TOTAL PER ANNUM } & & \multirow[b]{2}{*}{ TOTAL RAISED } \\
\hline & YEAR & MIN & MAX & & & \\
\hline USM & 1988 & 1,000 & 6,000 & 628,000 & $2.5 b n$ & (since 1981) \\
\hline Venture Capital - UK (incl. 3i Group) & 1988 & 150 & 2,250 & $1,298,000$ & $N / A$ & \\
\hline 3i Group - worldwide & $1987 / 8$ & 25 & 1,000 & 503,000 & $1.8 \mathrm{bn}$ & (since 1983) \\
\hline BES - Prospectus ** & $1986 / 7$ & 500 & 2,000 & 115,200 & 343,200 & $(1983 / 7)$ \\
\hline BES - Fund ${ }^{\star *}$ & $1986 / 7$ & 75 & 750 & 32,900 & 167,100 & $(1983 / 7)$ \\
\hline BES - Direct** & 1987 & 20 & 90 & 18,900 & 73,000 & $(1983 / 7)$ \\
\hline LGS & $1988 / 9$ & 10 & 75 & 64,800 & 715,600 & (since 1981) \\
\hline SDA & $1986 / 7$ & N/A & $N / A$ & 18,656 & 47,306 & \\
\hline
\end{tabular}

[Bank Lending 1989: It is estimated that approximately £30bn is outstanding in loans and overdrafts to SMEs]

Notes

* Range; approximate figures, excluding bottom/top 10 per cent.

** Official Inland Revenue Statistics. For later figures, see Table 5.

Source: 3i Group, Bank of England, Inland Revenue, Venture Economics Ltd, Department of Employment, SDA, Investment and Tax Planning Services. 


\footnotetext{
${ }^{1}$ See, for example, D. J. Goacher et al., Non-Bank Financial Intermediaries, London: Allen \& Unwin, 1987. The author acknowledges the help of his former colleague Dr David Goacher, Principal Lecturer at Sheffield City Polytechnic, in compiling this article.
}

\section{REFERENCES}

Batchelor, C., 1988, 'From Mega Egos to Recalcitrant Disks', Financial Times, 16 August.

(Bolton) Cmnd 4811, 1971, Report of the Committee of Enquiry on Small Firms, London: HMSO.

Comptroller and Auditor General, Department of Employment and Training Commission, 1988, Assistance to Small Firms, London: HMSO.

CBI City/Industry Task Force, England, 1987, Investing in Britain's Future.

Goacher, D.J., P.J. Curwen, R. Apps, J.G. Boocock, P.F. Cowdell and L. Drake, 1987, British Non-Bank Financial Intermediaries, London: Allen \& Unwin.

Harrison, R.T. and C.M. Mason, 1986, 'The Regional Impact of the Small Firms Loan

Guarantee Scheme in the United Kingdom', Regional Studies, Vol.20, No.6.

Lloyd, S., 1988, 'A Maturing Market', Accountancy, February.

Lorenz, A., 1985, Venture Capital Today, Cambridge: Woodhead-Faulkner.

(Macmillan) Cmnd 3897, 1931, Report of the Committee on Finance and Industry, London: HMSO, Ch.4, Part II, para.4.

Mason, C.M., J. Harrison and R.T. Harrison, 1988, Closing the Equity Gap? An Assessment of the Business Expansion Scheme, London: Small Business Research Trust.

NEDO, London, 1986, External Capital for Small Firms: A Review of Recent Developments, March.

NEDO, London, 1986, Lending to Small Firms: A Study of Appraisal and Monitoring Methods, July.

NEDO, London, 1986, Finance for Growth: A Study of Small and Medium-Sized Firms in the Electronics Sector, September.

Peat Marwick, 1986, The Business Expansion Scheme, London: Inland Revenue.

(Radcliffe), Cmnd 827, 1959, Report of the Committee on the Working of the Monetary System, London: HMSO.

Robson Rhodes, 1984, A Study of Businesses Financed Under the Small Business Loan Guarantee Scheme, DTI.

Storey, D.J., K. Keasey, R. Watson and P. Wynarczyk, 1987, The Performance of Small Firms, Beckenham: Croom Helm.

(Wilson) Cmnd 7503, 1979, The Financing of Small Firms, (Interim Report of the Committee to Review the Functioning of Financial Institutions), London: HMSO. 